\title{
Geographic variations in hip fracture incidence in a high-risk country stretching into the Arctic: a NOREPOS study
}

\author{
L. Forsén ${ }^{1} \cdot$ A. J. Søgaard ${ }^{1} \cdot$ K. Holvik ${ }^{1} \cdot$ H. E. Meyer ${ }^{1,2} \cdot$ T. K. Omsland ${ }^{2} \cdot$ H. Stigum ${ }^{1,2} \cdot$ C. Dahl ${ }^{2}$ (D)
}

Received: 23 October 2019 / Accepted: 12 February 2020 / Published online: 24 February 2020

(C) The Author(s) 2020

\begin{abstract}
Summary There are geographic variations in hip fracture incidence rates across Norway, with a lower incidence in the coastal areas of the southwest and in the Arctic north, contrary to what may be expected with regard to vitamin D exposure from sunlight. The regional differences have become smaller in recent years.

Introduction To investigate geographic variation in hip fracture incidence within Norway and regional differences in time trends. Methods All hip fractures treated in Norwegian hospitals 2002-2013 were included, and demographic information was obtained from Statistics Norway. Age-standardized incidence rates were calculated separately for 19 counties. Incidence rate ratios with 95\% confidence intervals for county differences and time trends were estimated using Poisson regression.

Results Age-standardized number of hip fractures per 10,000 person-years varied between counties from 69 to 84 in women and from 34 to 41 in men. The highest rates were observed in the southeastern capital city of Oslo, while rates were low in the four northernmost counties. There was an east-west gradient, with lower incidence in the coastal southwest compared with the southeast. Women showed a statistically significant decline during 2002-2013 in almost all counties (up to 31\%). In men, only a few counties showed a decline. In both genders, hip fracture rates at age 80 in the combined five counties with the highest rates were significantly higher than in the combined five counties with the lowest rates across the period, although the trends converged over time.

Conclusions In Norway, the hip fracture incidence was lower in the north compared with the south. In addition, we observed an east-west gradient with the highest incidence in the southeast and lower incidence in the coastal southwest. While there has been an overall declining trend in hip fracture incidence over time, regional differences are still apparent.
\end{abstract}

Keywords Epidemiology $\cdot$ Geographic variations $\cdot$ Hip fracture $\cdot$ Trend

\section{Introduction}

Age-standardized hip fracture rates in Norway increased until the beginning of the 1990s [1], and after plateauing, the

NOREPOS: Norwegian Epidemiologic Osteoporosis Studies

Electronic supplementary material The online version of this article (https://doi.org/10.1007/s00198-020-05346-8) contains supplementary material, which is available to authorized users.

C. Dahl

cecilie.dahl@medisin.uio.no

1 Department of Chronic Diseases and Ageing, Norwegian Institute of Public Health, Oslo, Norway

2 Department of Community Medicine and Global Health, Institute of Health and Society, University of Oslo, P.O. Box 1130, Blindern, N-0318 Oslo, Norway incidence declined during 1999-2013 [2, 6]. Despite this decline, Norway has among the highest reported hip fracture incidence rates in the world [4-6]. Comparable secular trends have been observed in many Western societies [6-9]. Although the age-standardized risk has been declining, the burden of hip fractures to society is projected to increase markedly in the future as the population ages [4, 10-12].

Secular trends and incidence rates of hip fracture vary substantially, both between countries [4-9] and within countries [13-17]. These geographic disparities have been explored through indicators of urban versus rural residence and population density on one hand, and indicators related to seasonal variation, weather conditions, temperature and climate on the other [16-24]. Differences in hip fracture incidence have also been linked to latitude, with higher incidence rates in high latitude regions [8, 25-28]. These findings are consistent with a role of vitamin D (exposure to UVB sunlight) in hip fracture 
causation $[21,25,26,28,29]$. However, higher hip fracture rates have been observed at lower latitude in other studies, for example within the USA [13], France [14] and England [15].

Norway is a far-stretched Scandinavian country, with the mainland extending from 58 to $71^{\circ}$ north, and it has substantial coast-inland, latitudinal and seasonal variations in temperature and climate. Interestingly, the two northernmost counties of Troms and Finnmark $\left(68-71^{\circ} \mathrm{N}\right)$ have historically had lower hip fracture rates than regions farther south [17, 30, 31]. Previous data are old, small and scattered, and may not represent more recent geographic variations in fracture risk. Knowledge about geographic variations in trends is a requirement for the ability to forecast future health and societal burden, to plan healthcare services, and as a basis for further research on the complex aetiology of hip fracture. Based on previous studies, we hypothesized that there would not be a latitudinal gradient in hip fracture incidence in Norway, but rather that fracture rates would be higher in counties with the highest proportion of urban dwellers. It is also unknown whether the declining risk of hip fracture observed over the recent decade has been similar across geographic regions, or whether some regions have been left behind.

The aim of the present study was to describe the geographic variation in incidence of hip fractures 2002-2013 across counties in Norway and to explore whether the rate of decline during this period differed according to county.

\section{Material and methods}

\section{Data sources}

All hip fractures treated in Norwegian hospitals with a diagnosis code for cervical, trochanteric or sub-trochanteric hip fracture (ICD 9: 820 with all subgroups; ICD 10: S72.0S72.2) between 1 January 1994 and 31 December 2013 were retrieved. Data were obtained from the Norwegian Knowledge Centre for the Health Services (until 2008) and from the Norwegian Patient Registry (NPR, through 2013). Patients with a hip fracture diagnosis code and surgical procedure code indicating hip fracture surgery were included. In cases with ambiguous information, a comprehensive algorithm was used to identify incident hip fractures by taking surgical procedure codes, diagnosis codes and time between hospitalizations into account. Dates of admission and discharge were available for all hospitalizations. Based on this information, admissions for primary hip fractures were identified. Age at discharge was calculated. Information on definitions, classification, quality assurance and validation of the data may be found online: www.norepos.no/documentation. Up to two hip fractures per person were included. Information on county of residence for the hip fracture patients was obtained from the Norwegian Population and Housing
Census 2001 carried out by Statistics Norway. Only hip fractures occurring during the period 2002-2013 were included. Demographics of the background population was retrieved online from Statistics Norway from 1 January 2002 to 31 December 2013 (http://ssb.no/en/).

\section{Statistical methods}

Gender- and county-specific hip fracture rates for each of the calendar years 2002 through 2013 were calculated using the mid-year population in 1-year age groups (50103 years) as an approximation to the population at risk each year. The mid-year population was defined as the arithmetic mean of the number of individuals within the gender and county category having the index age on January 1st of the respective calendar year and the number of individuals having index age +1 on January 1st of the subsequent calendar year. Age-standardization was performed by the direct method using the mean of the age distribution in 2013 in Norway in 1-year age groups as standard population, separately for each gender. Poisson regression was used to estimate incidence rate ratios (IRRs) with $95 \%$ confidence intervals (CI) for each county compared with Oslo adjusted for age and year in women and men separately. The county of Oslo was used as reference because it is known to have had the highest ever-observed incidence rates of hip fracture [1]. In additional analyses, the same calculations were done for women and men stratified by age $(<80$ years and $\geq 80$ years, respectively). Geographic variations in women and men combined were visualized using a colour-gradient map representing mean age-standardized hip fracture rate during 2002-2013 for each county.

To investigate within-county changes in incidence rates over the period 2002-2013, we computed the IRR between age-standardized hip fracture rates in 2013 and 2002 using Poisson regression. Graduated time trend curves were constructed, combining the five counties with the highest and the five counties with the lowest incidence rates, respectively. The five counties with the highest rates were the same in men and women, whereas the five counties with the lowest rates were somewhat different. Confidence bands were included to test for differences between the curves.

\section{Ethics}

The study and the linkages of data were approved by the Regional Committee for Medical and Health Research Ethics, the Norwegian Data Protection Agency, the Directorate of Health, The Norwegian Patient Registry, the Norwegian Institute of Public Health and Statistics Norway. 


\section{Results}

The average number of hip fractures per year in Norway 2002-2013 was 9182 (6502.5 in women and 2679.5 in men) (Table 1 and Supplementary Table 1). In most counties, the mean age-standardized hip fracture rate was more than double in women compared with men (Table 1 and Supplementary Table 1). The incidence rates in Oslo were, for example, 84 in women versus 41 in men per 10,000 person-years. The analyses stratified by age ( $<80$ years and $\geq 80$ years) revealed mainly the same results in women as shown in Table 1, whereas the number of fractures in men in several countries was too few to conclude. In persons 80 years and above, the relative gender differences were much smaller-in Oslo, the incidence was 358 in women and 225 in men. The county-specific agestandardized incidence rates of hip fracture in women ranged from 69 to 84 per 10,000 person-years in women, and from 34 to 41 per 10,000 person-years in men (Table 1). The capital city of Oslo, which also represents the most populated county, had the highest mean age-standardized hip fracture rates for both genders (Table 1 and Supplementary Table 1). Compared with Oslo, women in the county with the lowest agestandardized incidence rate (Sogn and Fjordane) had a 17\% lower incidence rate (IRR 0.83, Table 1). The corresponding difference in men between Oslo and the county with the lowest incidence rate (Nord-Trøndelag) was $15 \%$ (IRR 0.85, Supplementary Table 1).

Both women and men in the four northernmost counties (Nord-Trøndelag, Nordland, Troms and Finnmark) had significantly lower hip fracture incidence rates than Oslo situated much farther south (Table 1 and Supplementary Table 1, Fig. 1).
Table 1 Number of hip fractures, mean age-standardized incidence rates of hip fracture and incidence rate ratios compared with Oslo in women in 19 counties in Norway 2002-2013

\begin{tabular}{|c|c|c|c|c|c|c|}
\hline \multirow[t]{2}{*}{ County ${ }^{1}$} & \multirow{2}{*}{$\begin{array}{l}\text { Number } \\
\text { of hip } \\
\text { fracture }\end{array}$} & \multirow{2}{*}{$\begin{array}{l}\text { Crude incidence } \\
\text { of hip fractures } \\
\text { per } \\
10,000 \text { person- } \\
\text { years }\end{array}$} & \multirow{2}{*}{$\begin{array}{l}\text { Age-standardized } \\
\text { incidence of hip } \\
\text { fracture per } \\
10,000 \text { person- } \\
\text { years }^{2}\end{array}$} & \multicolumn{3}{|c|}{$\begin{array}{l}\text { Incidence rate ratio IRR of county } \\
\text { versus } \mathrm{Oslo}^{3}\end{array}$} \\
\hline & & & & IRR & $95 \% \mathrm{CI}$ & $\begin{array}{l}\% \\
\text { difference } \\
\text { versus } \\
\text { Oslo }\end{array}$ \\
\hline $\begin{array}{l}\text { Sogn og } \\
\text { Fjordane }\end{array}$ & 1854 & 81 & 69 & 0.83 & $.79-.87$ & -17 \\
\hline Vest-Agder & 2407 & 72 & 70 & 0.86 & $.82-.89$ & -14 \\
\hline Nord-Trøndelag & 2083 & 73 & 70 & 0.85 & $.81-.89$ & -15 \\
\hline Finnmark & 897 & 63 & 71 & 0.86 & $.80-.92$ & -14 \\
\hline Hordaland & 7296 & 79 & 74 & 0.89 & $.86-.92$ & -11 \\
\hline Rogaland & 5450 & 74 & 75 & 0.90 & $.87-.93$ & -10 \\
\hline Nordland & 4169 & 79 & 75 & 0.90 & $.87-.94$ & -10 \\
\hline Troms & 2226 & 71 & 75 & 0.90 & $.86-.95$ & -10 \\
\hline $\begin{array}{l}\text { Møre og } \\
\quad \text { Romsdal }\end{array}$ & 4492 & 83 & 75 & 0.91 & $.88-.94$ & -9 \\
\hline Buskerud & 4195 & 76 & 77 & 0.93 & $.89-.96$ & -7 \\
\hline Hedmark & 3781 & 82 & 77 & 0.95 & $.93-.98$ & -5 \\
\hline Aust-Agder & 1790 & 79 & 79 & 0.95 & $.98-.99$ & -5 \\
\hline Vestfold & 4070 & 81 & 80 & 0.97 & $.93-1.00$ & -3 \\
\hline Akershus & 6956 & 69 & 80 & 0.97 & $.94-1.00$ & -3 \\
\hline Sør-Trøndelag & 4640 & 82 & 81 & 0.99 & $.95-1.00$ & -1 \\
\hline Østfold & 4905 & 82 & 82 & 1.00 & $.97-1.03$ & 0 \\
\hline Oppland & 3795 & 87 & 83 & 1.01 & $.97-1.05$ & 0 \\
\hline Telemark & 3436 & 89 & 83 & 0.98 & $.97-0.99$ & -2 \\
\hline Oslo & 9588 & 94 & 84 & $\begin{array}{l}1.00 \\
\text { (ref.) }\end{array}$ & - & \\
\hline All 19 counties & 78,030 & & & & & \\
\hline
\end{tabular}

${ }^{1}$ Counties sorted in ascending order by incidence rate

${ }^{2}$ Age standardization with standard population: women 2013 in Norway

${ }^{3}$ Calendar year and age-adjusted comparison between each county versus Oslo (Poisson regression, dependent variable: number of hip fractures, independent variables: calendar year, county, age) 
There was an east-west gradient in hip fracture incidence among women: the counties along the coast from Vest-Agder in the south to Møre and Romsdal in the mid-west had lower incidence rates than the southeast counties of Oslo, Oppland and Telemark (Table 1 and Supplementary Table 1 and Fig. 1). The incidence rate in the county of Sogn and Fjordane (women and men combined) was $84 \%$ of the corresponding rate in Oslo (Table 1, Supplementary Table 1, Fig. 1).

Overall, hip fracture rates declined from 2002 to 2013 by $19 \%$ in women and $10 \%$ in men (Table 2 and Supplementary Table 2). Declining age-standardized hip fracture rates were observed in women in all counties, although the decline in three of the counties was not statistically significant (Table 2). In the 16 counties with a statistically significant decline, the rate of decline in women ranged from 14 to $31 \%$ (Table 2). The corresponding time trends among men did not show this clear trend, and with less variation across counties. Only four counties exhibited a statistically significant decline over the period (Supplementary Table 2). However, two of the counties with the highest incidence (Supplementary Table 1) also had the greatest decline-i.e. $26 \%$ in Sør-Trøndelag and 24\% in Telemark (Supplementary Table 2).

When summarizing the time trends for the five counties with the highest, and the five with the lowest crude trends based on the order in Table 1 and Supplementary Table 1, there was a statistically significant difference between the highest and the lowest group, and the curves started converging in the last years of the period 2002 to 2013 (Fig. 2). There was a corresponding development in the trend curves for men (Fig. 2), but the gap between the two curves was narrower in men compared with women.

\section{Discussion}

The age-standardized incidence rates of hip fracture in women were about twice as high as in men in all counties. Both women and men in the four northernmost counties $\left(64.5\right.$ to $\left.71^{\circ} \mathrm{N}\right)$ had lower hip fracture incidence rates than those living in Oslo (the capital city at $60^{\circ} \mathrm{N}$ ). Women living along the coast from the south to mid-Norway (southwest) had lower incidence rates than those living in the southeastern counties. The same pattern could be seen when the rates for women and men were combined.

In women, almost all counties had a declining trend in hip fracture incidence rates between 2002 and 2013, although the relative decline differed between counties. In men, some of the counties with the highest rates appeared to have the largest relative decline in the period. The curves for the five counties with the highest and the five with the lowest incidence rates converged (but did not coincide) in both genders throughout the period 2002-2013.
Fig. 1 Geographic variations in women and men combined, visualized using a colour-gradient map representing mean age-standardized hip fracture rate during 2002-2013 for each county

\section{Geographic differences}

\section{Latitude}

A study from Sweden, Norway's closest neighbour to the east, reported higher incidence rates of hip fracture at higher latitudes [25]. The authors argued that the higher incidence rates found in regions of higher latitudes are consistent with a role of vitamin D in hip fracture causation [25], a conclusion also supported by other researchers [21, 26, 28, 29].

In the northern part of Norway, above the Arctic Circle $\left(66^{\circ}\right.$ $33^{\prime} \mathrm{N}$ ), there are extreme variations in daylight between winter and summer. During mid-winter, there is only twilight a few hours a day in the northern part. The farther north, the longer the period of the year with insufficient UVB exposure for dermal vitamin D synthesis. However, contrary to what may be expected, we observed lower rates of hip fracture at higher latitudes in Norway. Our results confirm earlier findings from Norway: lower rates in Finnmark and Harstad (a city in the county of Troms) compared with Oslo [17, 30-32]. Our findings are also in line with a few other studies. Canadians had lower hip fracture rates than people in the USA farther south [33], and studies within France [14] and within England [15] showed lower fracture rates at higher latitudes.

\section{Proximity to the sea and fish consumption}

We may speculate that important fracture-preventing factors at higher latitudes could have counteracted the lower exposure to sunlight - and thus vitamin D supply, in the north. Low supply of vitamin $\mathrm{D}$ is, however, not one of the main risk factor for fracture. Indeed, in the adult and older population living at $69^{\circ} \mathrm{N}$, vitamin $\mathrm{D}$ status is relatively good; clearly better than one may expect based on the availability of sunshine, and better than in populations farther south in Europe [34]. Fish and seafood also contain other nutrients that could possibly contribute beneficially in bone health, such as, e.g. marine omega-3 fatty acids, high-quality protein and other vitamins (vitamin A, vitamin B12, vitamin E) and minerals (iodine, selenium). Some of the richest seas in the world surround Northern Norway, and seafood has been the main ingredient in the traditional diet throughout generations. The rich access to fresh fish throughout lifetime could be one of the possible explanations for the lower risk of hip fracture incidence in the north of Norway. Additionally, we found lower hip fracture rates along the southwestern coast of Norway compared with the southeast inland counties that are distant from the sea. The seven counties with the largest fishing industry of wild-living seafood in 2001 (https://www.nrk.no/mr/norges-storste- 


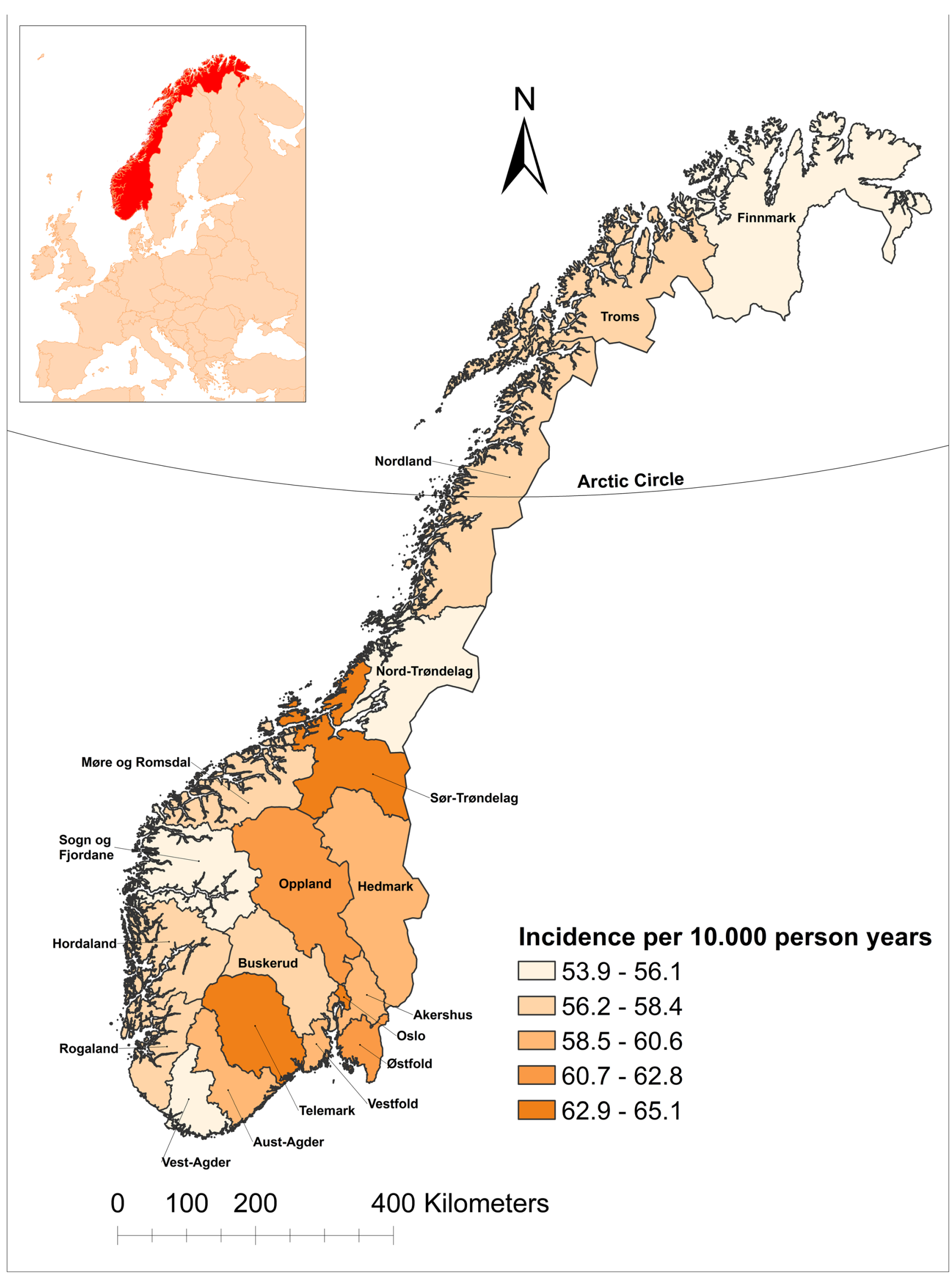


fiskerifylke-1.287978) all lie along the northern and western coast and were among the counties with the lowest agestandardized hip fracture rates among women (Table 1).

\section{Ethnicity}

In the three northernmost counties, there is historically an ethnic diversity of residents. About $60 \%$ of the participants in the Finnmark Study (aged 20-62 years in 1987/1988) had an ethnic Norwegian background, whereas the remainder of the participants responded to have two or more grandparents with Sami or Finnish ancestry [35]. Those with Sami and/or Finnish ancestry have on average a higher BMI and are of shorter stature [36]. Both these factors are beneficial when it comes to risk of hip fracture [37], and could as such contribute to the lower incidence in the northernmost regions.

\section{Urban-rural living}

Several studies have reported higher hip fracture rates in densely populated cities and areas (termed "urban"),

Table 2 Incidence rate ratio IRR per 12-year period in women in 19 counties in Norway 2002-2013

\begin{tabular}{|c|c|c|c|}
\hline \multirow[t]{2}{*}{ County ${ }^{1}$} & \multicolumn{3}{|c|}{ IRR per 12 -year period } \\
\hline & $\mathrm{IRR}^{2}$ & $95 \% \mathrm{CI}$ & $\begin{array}{l}\% \text { difference per } \\
12 \text {-year period }\end{array}$ \\
\hline Sogn og Fjordane & 0.73 & $(0.62,0.85)$ & -27 \\
\hline Vest-Agder & 0.78 & $(0.68,0.89)$ & -22 \\
\hline Nord-Trøndelag & 0.76 & $(0.65,0.88)$ & -24 \\
\hline Finnmark & 0.87 & $(0.70,1.10)$ & -13 \\
\hline Hordaland & 0.83 & $(0.77,0.94)$ & -17 \\
\hline Rogaland & 0.86 & $(0.79,0.95)$ & -14 \\
\hline Nordland & 0.88 & $(0.79,0.98)$ & -12 \\
\hline Troms & 0.97 & $(0.84,1.12)$ & -3 \\
\hline Møre og Romsdal & 0.80 & $(0.72,0.88)$ & -20 \\
\hline Buskerud & 0.84 & $(0.75,0.93)$ & -16 \\
\hline Hedmark & 0.86 & $(0.77,0.96)$ & -14 \\
\hline Aust-Agder & 0.86 & $(0.75,1.01)$ & -4 \\
\hline Vestfold & 0.73 & $(0.65,0.81)$ & -27 \\
\hline Akershus & 0.76 & $(0.70,0.82)$ & -24 \\
\hline Sør-Trøndelag & 0.76 & $(0.69,0.84)$ & -31 \\
\hline Østfold & 0.83 & $(0.75,0.92)$ & -17 \\
\hline Oppland & 0.79 & $(0.71,0.89)$ & -21 \\
\hline Telemark & 0.79 & $(0.70,0.89)$ & -21 \\
\hline Oslo & 0.84 & $(0.79,0.90)$ & -16 \\
\hline Total Women & 0.81 & $(0.79,0.83)$ & -19 \\
\hline
\end{tabular}

${ }^{1}$ Counties sorted in ascending order by incidence rate (see Table 1)

${ }^{2}$ Incidence rate ratio (IRR) for the whole period 2002-2013 adjusted for age, county (with Oslo as ref.) and calendar years (Poisson regression) compared with areas with lower population density ("rural") [38]. The north of Norway is less densely populated with relatively more rural areas than the south. However, the second and third largest Norwegian cities, Bergen and Stavanger/ Sandnes, are both located in the low-incidence west-coast counties of Hordaland and Rogaland, respectively (Table 1 and Supplementary Table 1, Fig. 1). Furthermore, there are sparsely populated areas also in some of the southeastern counties (Telemark, Oppland) with relatively high fracture incidence. Thus, our findings are not fully consistent with an urban-rural difference in hip fracture incidence. Moreover, in the north of Sweden, where hip fracture incidence was higher than in the south of Sweden, the inhabitants are mainly living in rural areas and small villages [25].

\section{Climate and temperature}

The finding of apparently lower fracture rates in the coastal counties in the southwest compared with some of the counties in the southeast could perhaps be partly explained by milder winters with higher average temperatures and less ice and snow in the southwest [39]. On the other hand, the majority of fractures occur indoors [1], although there seems to be an increase in indoor incidence on snow-covered days among community dwellers in Sweden [20]. Furthermore, the inland municipalities in Finnmark (with lower incidence) have lower mean temperature (i.e. far below freezing point) and less monthly precipitation than most other municipality in Norway [39].

\section{Other possible explanations}

We may speculate that geographic variations in individual risk factors such as BMI, physical activity and cigarette smoking have contributed to the observed geographic variation in fracture risk. Self-reported information on lifestyle factors is available in a nationwide sample of respondents 67 years and older who participated in a 2008 survey on living conditions (Statistics Norway). Daily smoking has traditionally been more common in the north of Norway, but the percentage of daily smokers was about the same in the north compared with the rest of the country in 2008 [40]. The percentage reporting to be inactive was higher in Northern Norway compared with the southwest and the southeast of the country - and the percentage reporting to "exercise weekly or more often" was lower in the north [40]. Thus, none of these factors seems to contribute in explaining the lower fracture rates in the north. However, Northern Norway had the highest percentage reporting BMI $\geq 25$ based on self-reported weight and height [40]. Thus, BMI differences could play a role, but Telemark, a high-incidence county in the southeast, had the same percentage individuals with BMI $>25$ as the low-incidence county of Finnmark farthest north (Table 1 and Fig. 1). 


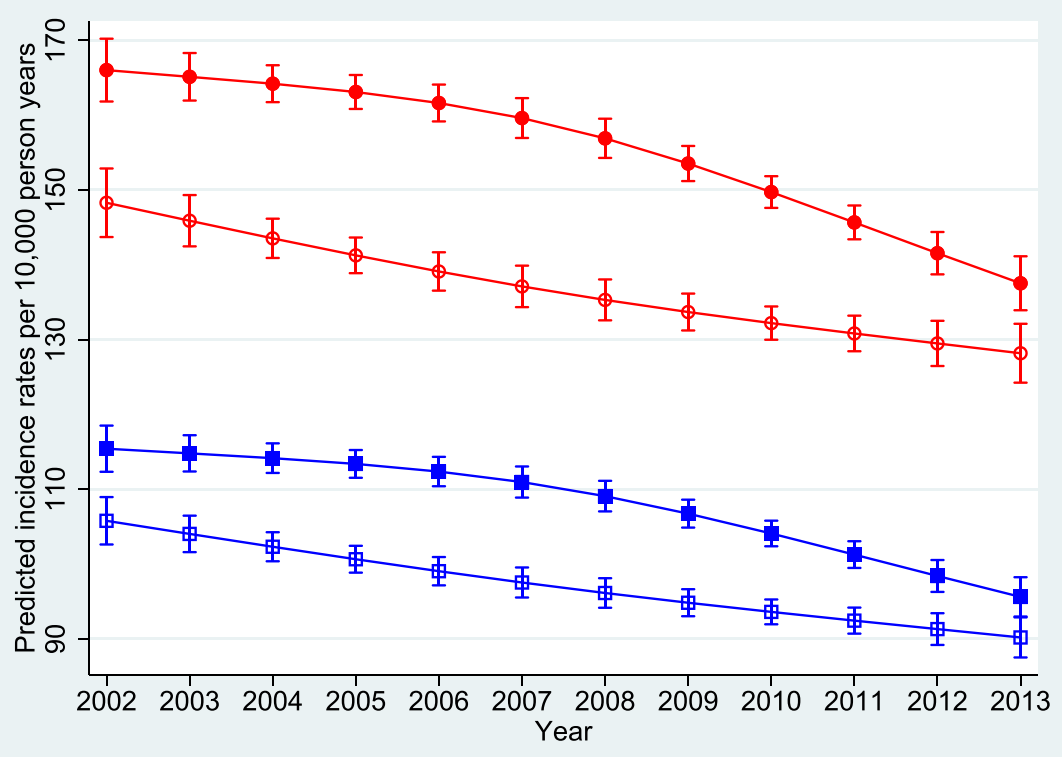

Fig. 2 Predicted hip fracture incidence rates in the five counties with highest versus the five counties with the lowest age-standardized rates in women (red lines) and men (blue lines). Predicted margins per 10,000 person-years with $95 \%$ confidence intervals, set at 80 years during the period 2002-2013. Filled circles indicate counties with the highest incidence rate in women (Oslo, Telemark, Oppland, Østfold, SørTrøndelag combined), open circles indicate the five counties with the lowest incidence rates in women (Sogn og Fjordane, Vest-Agder, NordTrøndelag, Finnmark and Hordaland) combined. Filled squares indicate the counties with the highest incidence rate in men (same as in women) combined, and open squares indicate the five counties with the lowest incidence rates in men (Nord-Trøndelag, Rogaland, Vestfold, AustAgder, Hordaland combined)

\section{Time trends}

Although the rate of decline in hip fracture incidence during 2002-2013 was consistent across counties with a few exceptions, the gap in hip fracture rates between the Norwegian counties seems to have narrowed over the last decades. The incidence of hip fractures in the southwestern county of Sogn and Fjordane was $65 \%$ of that in Oslo in 1988/1989 [41], 72\% in 1994/1995 [31] and $84 \%$ in our data for the period $2002-$ 2013.

The five counties with the highest rates were the same in men and women, whereas the five counties with the lowest rates differed somewhat between genders. The differences in age-standardized number of hip fractures per 10,000 personyears between the nine counties with the lowest rates in men were, however, negligible (2/10,000 person-years) (Supplementary Table 1).

An apparent decline in almost all counties in women, irrespective of the incidence in 2002, is consistent with a role of structural changes acting in the whole countryfor example healthier older adults [42], increased BMI [43] and decreased prevalence of cigarette smoking [43]. There may also be differences in bone mineral density that we have not been able to explore. We would have expected that the introduction of new types of antiosteoporotic medications (AOD) could have increased the use of these drugs - and consequently contributed to the decrease in hip fracture incidence. However, from 2004 to 2013, the dispensing of AOD in pharmacies in Norway was stable or slightly declining [44]. In the period from 2008/2009 until 2014/2015, there was a small, but statistically significant, decline in the proportion of adults who were insufficiently physically active based on objective measurements, while data based on questionnaires indicate a small increase in the proportion reporting insufficient physical activity [43]. Thus, increasing AODuse or decreasing physical activity is probably not important in explaining the change in hip fracture incidence. However, Norway as many other European countries have had an increase in immigration by individuals from countries with lower fracture incidence. Foreign-born individuals in Sweden have been found to have a reduced risk of hip fracture [45]. In Norway, the immigrant population is still relatively young and the majority of persons born in other countries have not yet reached the peak age associated with high hip fracture incidence. Still, this will be relevant to pursue in future analyses. Other structural conditions that could in theory be associated with declining fracture rates are the introduction of unleaded gasoline in the 1980 s, climate changes and/or less acid rain.

Since Norway has one of the highest fracture risks worldwide, studies in the Norwegian population presents unique opportunities to further explore risk factors for fracture incidence and the decline. 


\section{Strengths and limitations}

The strengths of this study are the nationwide inclusion of a large number of hip fractures, the validity and completeness of the NORHip database (www.norepos.no/documentation) and the long follow-up period. Using a combination of diagnostic and procedure codes, a high accuracy of the total number of hip fractures has been achieved $(98.2 \%)$ [3, 46]. Although we have complete hip fracture data from 1994 for most counties and from 1999 for all counties (www.norepos.no/ documentation), only hip fractures occurring in the period 2002-2013 were included to avoid immortal time bias. Complete demographics of the background population was retrieved online from Statistics Norway from 1 January 2002 to 31 December 2013 (http://ssb.no/en/).

\section{Conclusion}

Studies of geographic differences in hip fracture incidence and trends within countries may provide important clues to aetiology and prevention. We found that there are geographic variations in hip fracture incidence rates across Norway, with a lower incidence in the coastal areas of the southwest and in the Arctic north, contrary to what may be expected with regard to vitamin D exposure from sunlight. The regional differences have become smaller in the recent years, but the overall decline in incidence has not happened equally in all counties. The reasons for these differences are unclear, and will be further explored in future NOREPOS on variations in climate and geography and the relation to hip fracture incidence.

\begin{abstract}
Acknowledgements Data from the Norwegian Patient Registry has been used in this publication. Staff in the Norwegian Institute of Public Health (previously the National Health Screening Service) and Statistics Norway is acknowledged for data collection and linkage to hip fracture data. The authors thank Jon Wickmann at the Norwegian Institute of Public Health for his valuable contribution in data preparation and quality assurance. Many thanks also to Solveig Sakshaug, Norwegian Institute of Public Health, for extracting statistics from the Norwegian Prescription Database regarding the use of anti-osteoporosis drugs.
\end{abstract}

Funding Information Open Access funding provided by Oslo University \& Oslo University Hospital.

\section{Compliance with ethical standards}

The study and the linkages of data were approved by the Regional Committee for Medical and Health Research Ethics, the Norwegian Data Protection Agency, the Directorate of Health, The Norwegian Patient Registry, the Norwegian Institute of Public Health and Statistics Norway.

\section{Conflicts of interest None.}

Disclaimer The interpretation and reporting of these data are the sole responsibility of the authors, and no endorsement by the Norwegian Directorate of Health is intended nor should be inferred.

Open Access This article is licensed under a Creative Commons Attribution-NonCommercial 4.0 International License, which permits any non-commercial use, sharing, adaptation, distribution and reproduction in any medium or format, as long as you give appropriate credit to the original author(s) and the source, provide a link to the Creative Commons licence, and indicate if changes were made. The images or other third party material in this article are included in the article's Creative Commons licence, unless indicated otherwise in a credit line to the material. If material is not included in the article's Creative Commons licence and your intended use is not permitted by statutory regulation or exceeds the permitted use, you will need to obtain permission directly from the copyright holder. To view a copy of this licence, visit http://creativecommons.org/licenses/by-nc/4.0/.

\section{References}

1. Lofthus CM, Osnes EK, Falch JA, Kaastad TS, Kristiansen IS, Nordsletten L, Stensvold I, Meyer HE (2001) Epidemiology of hip fractures in Oslo, Norway. Bone 29:413-418

2. Omsland TK, Holvik K, Meyer HE, Center JR, Emaus N, Tell GS, Schei B, Tverdal A, Gjesdal CG, Grimnes G, Forsmo S, Eisman JA, Søgaard AJ (2012) Hip fractures in Norway 1999-2008: time trends in total incidence and second hip fracture rates: a NOREPOS study. Eur J Epidemiol 27:807-814

3. Søgaard AJ, Holvik K, Meyer HE, Tell GS, Gjesdal CG, Emaus N, Grimnes G, Schei B, Forsmo S, Omsland TK (2016) Continued decline in hip fracture incidence in Norway: a NOREPOS study. Osteoporos Int 27:2217-2222

4. Cheng SY, Levy AR, Lefaivre KA, Guy P, Kuramoto L, Sobolev B (2011) Geographic trends in incidence of hip fractures: a comprehensive literature review. Osteoporos Int 22:2575-2586

5. Kanis JA, Odén A, McCloskey EV, Johansson H, Wahl DA, Cooper C (2012) A systematic review of hip fracture incidence and probability of fracture worldwide. Osteoporos Int 2:2239-2256

6. Cauley JA, Chalhoub D, Kassem AM, El-Hajj Fuleihan G (2014) Geographic and ethnic disparities in osteoporotic fractures. Nat Rev Endocrinol 10:338-351

7. Cooper C, Cole ZA, Holroyd CR, Earl SC, Harvey NC, Dennison EM, Melton LJ, Cummings SR, Kanis JA (2011) Secular trends in the incidence of hip and other osteoporotic fractures. Osteoporos Int 22:1277-1288

8. Dhanwal DK, Dennison EM, Harvey NC, Cooper C (2011) Epidemiology of hip fracture: worldwide geographic variation. Indian J Orthop 45:15-22

9. Ballane G, Cauley JA, Luckey MM, El-Hajj Fuleihan G (2014) Secular trends in hip fractures worldwide: opposing trends East versus West. J Bone Miner Res 29:1745-1755

10. Omsland TK, Magnus JH (2014) Forecasting the burden of future postmenopausal hip fractures. Osteoporos Int 25:2493-2496

11. Odén A, McCloskey EV, Kanis JA, Harvey NC, Johansson H (2015) Burden of high fracture probability worldwide: secular increases 2010-2040. Osteoporos Int 26:2243-2248

12. Hagen G, Magnussen J, Tell G, Omsland T (2019) Estimating the future burden of hip fractures in Norway. A NOREPOS study. Bone 131:115156

13. Stroup NE, Freni-Titulaer LW, Schwartz JJ (1990) Unexpected geographic variation in rates of hospitalization for patients who have fracture of the hip. Medicare enrollees in the United States. J Bone Joint Surg Am 72:1294-1298 
14. Barbier S, Ecochard R, Schott AM, Colin C, Delmas PD, Jaglal SB, Couris CM (2009) Geographical variations in hip fracture risk for women: strong effects hidden in standardised ratios. Osteoporos Int 20:371-377

15. Curtis EM, van der Velde R, Moon RJ, van den Bergh JP, Geusens P, de Vries F, van Staa TP, Cooper C, Harvey NC (2016) Epidemiology of fractures in the United Kingdom 1988-2012: variation with age, sex, geography, ethnicity and socioeconomic status. Bone 87:19-26

16. Grønskag AB, Forsmo S, Romundstad P, Langhammer A, Schei B (2010) Incidence and seasonal variation in hip fracture incidence among elderly women in Norway. The HUNT Study. Bone 46: 1294-1298

17. Emaus N, Olsen LR, Ahmed LA, Balteskard L, Jacobsen BK, Magnus T, Ytterstad B (2011) Hip fractures in a city in Northern Norway over 15 years: time trends, seasonal variation and mortality. The Harstad Injury Prevention Study. Osteoporos Int 22:26032610

18. Lin HC, Xiraxagar S (2006) Seasonality of hip fractures and estimates of season-attributable effects: a multivariate ARIMA analysis of population-based data. Osteoporos Int 17:795-806

19. Bischoff-Ferrari HA, Orav JE, Barrett JA, Baron JA (2007) Effect of seasonality and weather on fracture risk in individuals 65 years and older. Osteoporos Int 18:1225-1233

20. Leavy B, Åberg AC, Melhus H, Mallmin H, Michaëlsson K, Byberg L (2013) When and where do hip fractures occur? A population-based study. Osteoporos Int 24:2387-2396

21. Pasco JA, Henry MJ, Kotowicz MA, Sanders KM, Seeman E, Pasco JR, Schneider HG, Nicholson GC (2004) Seasonal periodicity of serum vitamin D and parathyroid hormone, bone resorption, and fractures: the Geelong Osteoporosis Study. J Bone Miner Res 19:752-758

22. Modarres R, Ouarda TB, Vanasse A, Orzanco MG, Gosselin P (2014) Modeling climate effects on hip fracture rate by the multivariate GARCH model in Montreal region, Canada. Int $\mathrm{J}$ Biometeorol 58:921-930

23. Solbakken SM, Magnus JH, Meyer HE, Emaus N, Tell GS, Holvik K, Grimnes G, Forsmo S, Schei B, Søgaard AJ, Omsland TK (2014) Impact of comorbidity, age, and gender on seasonal variation in hip fracture incidence. A NOREPOS study. Arch Osteoporos 9:191

24. Román Ortiz C, Tenías JM, Estarlich M, Ballester F (2015) Systematic review of the association between climate and hip fractures. Int J Biometeorol 59:1511-1522

25. Odén A, Kanis JA, McCloskey EV, Johansson H (2014) The effect of latitude on the risk and seasonal variation in hip fracture in Sweden. J Bone Miner Res 29:2217-2223

26. Johnell O, Borgstrom F, Jonsson B, Kanis J (2007) Latitude, socioeconomic prosperity, mobile phones and hip fracture risk. Osteoporos Int 18:333-337

27. Bhimjiyani A, Neuburger J, Jones T, Ben-Shlomo Y, Gregson CL (2018) Inequalities in hip fracture incidence are greatest in the North of England: regional analysis of the effects of social deprivation on hip fracture incidence across England. Public Health 162: $25-31$

28. Norton R, Yee T, Rodgers A, Gray H, MacMahon S (1997) Regional variation in the incidence of hip fracture in New Zealand. N Z Med J 110:78-80

29. Mazzucchelli R, Crespí-Villarías N, Pérez-Fernández E, Durbán Reguera ML, Guzón Illescas O, Quirós J, García-Vadillo A, Carmona L, Rodriguez-Caravaca G, Gil de Miguel A (2018) Weather conditions and their effect on seasonality of incident osteoporotic hip fracture. Arch Osteoporos 13:28

30. Wasmuth HH, Reikerås O, Roald HE (1992) Hip fractures in Troms and Oslo in 1989. Risk development 1978-89. J Norw Med Assoc 112:190-193
31. Bulajic-Kopjar M, Wiik J, Nordhagen R (1998) Regional differences in the incidence of femoral neck fractures in Norway. $\mathrm{J}$ Norw Med Assoc 118:30-33

32. Falch JA, Ilebekk A, Slungaard U (1985) Epidemiology of hip fractures in Norway. Acta Orthop Scand 56:12-16

33. Leslie WD, O'Donnell S, Lagacé C, Walsh P, Bancej C, Jean S, Siminoski K, Kaiser S, Kendler DL, Jaglal S (2010) Populationbased Canadian hip fracture rates with international comparisons. Osteoporos Int 21:1317-1322

34. Cashman KD, Dowling KG, Škrabáková Z, Gonzalez-Gross M, Valtuena J, De Henauw S, Moreno L, Damsgaard CT, Michaelsen KF, Mølgaard C, Jorde R, Grimnes G, Moschonis G, Mavrogianni C, Manios Y, Thamm M, Mensink GB, Rabenberg M, Busch MA, Cox L, Meadows S, Goldberg G, Prentice A, Dekker JM, Nijpels G, Pilz S, Swart KM, van Schoor NM, Lips P, Eiriksdottir G, Gudnason V, Cotch MF, Koskinen S, Lamberg-Allardt C, Durazo-Arvizu RA, Sempos CT, Kiely M (2016) Vitamin D deficiency in Europe: pandemic? Am J Clin Nutr 103:1033-1044

35. Westlund K, Søgaard AJ (1993) Health, lifestyle and living conditions in Finnmark. Results from the cardiovascular survey 1987-88. Finnmark III. ISM publication series 28. University of Tromsø, Tromsø

36. Njølstad I, Arnesen E, Lund-Larsen PG (1998) Cardiovascular diseases and diabetes mellitus in different ethnic groups: the Finnmark study. Epidemiology 9:550-556

37. Meyer HE, Tverdal A, Falch JA (1993) Risk factors for hip fracture in middle-aged Norwegian women and men. Am J Epidemiol 137: 1203-1211

38. Brennan SL, Pasco JA, Urquhart DM, Oldenburg B, Hanna FS, Wluka AE (2010) The association between urban or rural locality and hip fracture in community-based adults: a systematic review. J Epidemiol Community Health 64:656-665

39. Tveito OE, Førland EJ, Alexandersson H, Drebs A, Jónsson T, Tuomenvirta H, Vaarby Laursen E (2001) Nordic climate maps. DNMI report no. 06/01. Norwegian Meterorological Institute, Norway

40. Statistics Norway (2008) Survey on living conditions 2008. Health, care and social relations. Statistics Norway. https://www.ssb.no/en/ statbank/table $/ 08284$

41. Falch JA, Kaastad TS, Bøhler G, Espeland J, Sundsvold OJ (1993) Secular increase and geographical differences in hip fracture incidence in Norway. Bone 14:643-645

42. Strand BH, Bergland A, Jørgensen L, Schirmer H, Emaus N, Cooper R (2019) Do more recent born generations of older adults have stronger grip? A comparison of three cohorts of 66- to 84year-olds in the Tromsø study. J Gerontol A Biol Sci Med Sci 74: $528-533$

43. Norwegian Institute of Public Health. Indicators for noncommunicable diseases connected to the national and global strategy for non-communicable diseases. https://www.fhi.no/en/op/ Indicators-for-NCD/. Accessed 24.09.2019

44. The Norwegian Prescription Database (2019) The Norwegian Prescription Database. www.norpd.no. Accessed 27.09.2019

45. Albin B, Hjelm K, Elmståhl S (2010) Lower prevalence of hip fractures in foreign-born individuals than in Swedish-born individuals during the period 1987-1999. BMC Musculoskelet Disord 11: 203

46. Hoiberg MP, Gram J, Hermann P, Brixen K, Haugeberg G (2014) The incidence of hip fractures in Norway -accuracy of the national Norwegian patient registry. BMC Musculoskelet Disord 15:372

Publisher's note Springer Nature remains neutral with regard to jurisdictional claims in published maps and institutional affiliations. 